\title{
LA INGENIERÍA, UNA DISCIPLINA AL SERVICIO DEL MUNDO
}

La ingeniería es una disciplina que está fundamentada en el uso de los conocimientos científicos, y su estrecha relación con otras áreas, como la investigación, el diseño, el desarrollo, la construcción, la producción, entre otros, permite transformar las ideas en acciones, las cuales conllevan la generación de soluciones que contribuyen a la resolución de problemas en cualquier sector de un país.

Siendo consecuentes con lo anterior, la conservación del ambiente se ha constituido en uno de los grandes retos a nivel mundial. Entre los objetivos de desarrollo sostenible se encuentra la mitigación del cambio climático, ya que este es uno de los problemas que más afecta la biosfera. Los datos estadísticos y científicos ${ }^{1}$ han demostrado que los fenómenos climáticos se ven perturbados por la concentración de los gases de efecto invernadero, emitidos a la atmósfera por el ser humano, producto de los patrones de consumo y producción concebidos por el crecimiento económico actual. ${ }^{2}$

En este orden de ideas, según los autores del artículo "Regulación de frecuencia en sistemas de potencias que integran fuentes de energía eólicas mediante un controlador PI imitación de inercia", el interés por las energías renovables (RES) se debe a que representan una alternativa real para disminuir la dependencia de fuentes de energía tradicionales, generar reducciones de gases de efecto invernadero antrópicos y contribuir con la diversificación energética de la creciente demanda.

Otro factor por considerar dentro de la conservación del ambiente corresponde a los ecosistemas, entendidos como el conjunto de órganos vivos y el medio físico donde se relacionan. En el ámbito suramericano, Colombia es un país privilegiado, ya que cuenta con una posición geográfica estratégica, una riqueza natural muy amplia y una biodiversidad del ecosistema.

1 Véase J. T. Houghton et al., Eds., "Summary for Policymakers: A Report of Working Group I of the Intergovernmental Panel on Climate Change", en Climate Change 2001: The Scientific Basis, New York, Us, University Press, 2001, p. 7.

2 W. Butze Aguilar, "El cambio climático: un problema de energía”, El Cotidiano, vol. 19, no. 23. Ene.-Feb. 2004, p. 67. [Online]. Disponible en: http://www.redalyc. org/articulo.oa?id=32512307
Dentro de esta biodiversidad de ecosistemas están los boscosos, tales como el bosque popular El Pardo en Manizales, Los Saltos Ecoparque de La Ceja, el Bosque de Palma de Cera en Salamina, la Vereda El Carmen de Villavicencio, el Paraíso de Bambú y la Guadua de Montenegro, entre otros; y ecosistemas no boscosos como el Nevado del Ruiz, la Sierra Nevada del Cocuy, la Sierra Nevada de Santa Marta, el Páramo de Berlín, situado entre Bucaramanga y Cúcuta, y el Páramo de Santurbán, rico por ofrecer un turismo sostenible, entre otros.

Lo anterior nos lleva a considerar que los habitantes de estos dos ecosistemas tienen una directa relación con los bienes y servicios que, desde allí, se pueden explotar en el buen sentido de la palabra.

Lo anterior se ve reflejado en el artículo "Consumo de productos forestales no madereros en el ámbito urbano: el caso de harinas de frutos de árboles de bosques nativos en el norte de Argentina", en el que se deja ver que los recursos forestales maderables y no maderables son importantes en el establecimiento de las sociedades y los estilos de vida urbanos; así mismo, se discute el consumo de productos forestales no madereros en el ámbito urbano, provenientes de los bosques nativos en el norte de Argentina, cuyo enfoque es el uso de harinas de frutos de diferentes tipos de plantas, en especial el Prosopis alba (algarrobo) por la variedad de usos conocidos por la comunidad.

Otro campo de acción de la ingeniería, hoy por hoy, es el de las tecnologías de la información y las comunicaciones (TIC), las cuales se aplican y causan gran impacto en cualquier disciplina. La ciencia de la salud no es la excepción, puesto que viene utilizando, según la Organización Mundial de la Salud (oms), diferentes formas de aplicación tecnológica, tales como telemedicina, telesalud y e-salud.

En la e-salud, según el artículo "Marco de referencia para la gestión de programas en e-salud", intervienen elementos socioculturales que juegan un papel clave en la adopción y apropiación de la tecnología.

La adopción de la convergencia tecnológica, el incentivo a la creación y al fortalecimiento de la infraestructura y, sobre todo, el cuidado de la calidad y la cobertura de los servicios de e-salud para que sean justos y asequibles a la población 
admiten un nuevo enfoque. Este es imprescindible al observar la condición y el potencial de las TIC como vehículo de prosperidad social.

Según los autores del estudio en cuestión, "el objetivo de este artículo es explorar el ecosistema de e-salud desde la perspectiva de la complejidad $y$ ofrecer un marco conceptual para hacer una aproximación sistemática con énfasis en la formulación y propuestas de implementación de políticas públicas que, por un lado, contribuyan a un mejor planteamiento de los proyectos, programas e intervenciones de e-salud, y, por otro, promuevan la creación de contextos de interacción en continuo aprendizaje para mejorar servicios y procesos de e-salud".

La ingeniería industrial se caracteriza por ser una profesión cuyos egresados tienen como objetivo fundamental diseñar procesos y procedimientos que ayudan a las organizaciones, en general, a mejorar de forma eficiente su productividad y, por ende, su competitividad. Esta afirmación se puede ver reflejada en el artículo "Mejora del proceso de fabricación de estibas de madera: un caso de estudio". En él, sus autores muestran el resultado del proyecto de investigación aplicada en el cual se persiguió como objetivo "generar y aplicar acciones de mejora al proceso productivo de la empresa estudiada a partir de herramientas propias de la ingeniería industrial que permitieran un mejor uso de recursos".

Las estibas o pallets sirven para el almacenamiento, la estandarización, el movimiento y el transporte de las mercancías. Estos elementos nos permiten disminuir la manipulación de materiales y productos, lo cual optimiza los gastos por deterioros de los mismos, y sus beneficios se ven reflejados en la protección de la mercancía y de los operarios, y en la eficiencia en las operaciones lógicas.

Las mejoras que se hicieron a la fabricación de las estibas se centraron particularmente en el estudio de métodos y tiempos, así como en los cálculos para el rendimiento de la madera, la utilización de la metodología o las estrategias de las 5S (clasificación, orden, limpieza, limpieza estandarizada y disciplina) y la guía PML.

Estos artículos y otros de gran interés como "Propuesta de una arquitectura de la industria 4.0 en la cadena de suministro desde la perspectiva de la ingeniería industrial" y "Gestión de integridad en facilidades on shore con tecnología high definition survey (HDs) 3D" hacen parte de esta edición de la revista Ingeniería Solidaria, publicación relacionada con diferentes áreas de la disciplina que nos ocupa.

Iván Méndez Alvarado Ingeniero de sistemas 


\section{ENGINEERING, A DISCIPLINE AT THE WORLD'S SERVICE}

Engineering is a discipline based on the use of scientific knowledge, and its close relationship with other areas, such as research, design, development, construction and production, among others. It enhances the transformation of ideas into actions, which entail the creation of solutions that contribute to problem solving in any sector of a given country.

Consistently, environmental conservation has become one of the great challenges worldwide. Among the objectives of sustainable development, one may find the mitigation of climate change, since this is one of the main problems that affects the biosphere at the highest degree. Statistical and scientific data ${ }^{1}$ have shown that climatic phenomena increase due to the concentration of greenhouse gases, which are emitted into the atmosphere by humans as a result of the consumption and production patterns generated by current economic growth. ${ }^{2}$

In this regard, according to the authors of the article "Frequency regulation in power systems that integrate wind energy sources with a PI imitator of inertia", the interest in renewable energies (RES) is given by the fact that they represent an alternative to reduce the dependence on traditional energy sources, generate decreases of anthropogenic greenhouse gases, and contribute to energy diversification of the growing demand.

Another factor to consider within environmental conservation is that of ecosystems, understood as the group of living organisms and the physical environments in which they coexist. Considering South America, Colombia is a privileged country, since it has a strategical geographical location, widespread natural wealth, and the biodiversity of its ecosystem.

Within this biodiversity of ecosystems, it is possible to name, for example, the popular forest of El Prado in Manizales, Los Saltos Ecoparque

1 See J. T. Houghton et al., Eds., "Summary for Policymakers: A Report of Working Group I of the Intergovernmental Panel on Climate Change", in Climate Change 2001: The Scientific Basis, New York: University Press, 2001, P. 7.

2 W. Butze Aguilar, "El cambio climático: un problema de energía”, El Cotidiano, vol. 19, no. 23. Jan.-Feb. 2004, p. 67. [Online]. Available: http://www.redalyc.org/articulo. oa?id=32512307 in La Ceja, the Wax Palm Forest in Salamina, the Vereda El Carmen in Villavicencio, and the Bamboo and Guadua Paradise in Montenegro, among others, and non-forested ecosystems such as the Nevado del Ruiz, Sierra Nevada del Cocuy, Sierra Nevada de Santa Marta, Páramo de Berlín -located between Bucaramanga and Cúcuta-, and Páramo de Santurbán -which offers sustainable tourism-, among others

This leads us to consider that inhabitants of these two ecosystems have a direct relationship with the goods and services that may be generated and exploited, in the good sense of the word.

The above can be reflected in the article "Consumption of non-timber yielding forest products in the urban area: The case of fruit flours from native forest trees in Northern Argentina", which shows that timber and non timber-yielding resources are important to establish urban lifestyles and societies. It also exposes the consumption of non-timber-yielding forest products in the urban environment, all of which come from native forests in Northern Argentina that focus in the use of fruit flours from different types of plants, especially Prosopis alba (carob), due to the variety of uses they have, and that are known by the community.

Another field of action of engineering today, is that of information and communication technologies (ICT), which generate great impact in any discipline. Health sciences are no exception; according to the World Health Organization (wHo), these have implemented different forms of technological application, for example, telemedicine, telehealth and e-health.

In e-health, according to the article "Reference framework for the management of e-health programs", socio-cultural elements intervene, and they have a key role in technology adoption and appropriation.

The adoption of technological convergence, the incentive to create and strengthen infrastructure, and, above all, the care for quality and coverage of e-health services -for them to be fair and affordable to all-admit a new focus. This approach becomes essential when observing the ICT condition and potential as a vehicle for social prosperity.

According to the authors of the article, "the objective of this article is to explore the ecosystem of e-health based on the complexity 
perspective and offer a conceptual framework to make a systematic approach that emphasizes on formulation and implementation proposals of public policies that, on the one hand, contribute to better planning of e-health projects, programs and interventions; and on the other hand, that promote the creation of interaction contexts for continuous learning to improve e-health services and processes."

What characterizes Industrial Engineering is that its career graduates have the fundamental objective of designing processes and procedures that help organizations to efficiently improve their productivity and, therefore, their competitiveness. This statement is made evident in the article "Manufacturing process of wooden stowage improvement: A case study." In it, the authors show the results of an applied research project which had the following objective: "To generate and apply actions to improve the production process of the studied company, using tools of industrial engineering that trigger a better use of resources."
Stowage serves for storage, standardization, movement and transport of goods. It helps to diminish handling of goods and products, which optimizes expenses made due to their deterioration, and its benefits reflect in merchandise and operators' protection, as well as in efficiency reached in logical operations.

Improvements made on stowage manufacture focus particularly on the study of methods and timing, as well as calculations for wood performance, methodology application, or strategies belonging to the $5 \mathrm{~S}$ (classify, organize, clean, standardized cleaning, and discipline), and the PML guide.

These articles, and others of great interest, such as "Industry architecture 4.0 proposal in the supply chain from the Industrial Engineering perspective," and "Integrity management in on-shore facilities with high definition 3D technology (НDT)" make part of volume 19, number 23, of Ingeniería Solidaria, a journal dedicated to different fields of Engineering.

\author{
Iván Méndez Alvarado \\ Systems Engineer \\ Network and Communications Specialist \\ Full time teacher \\ Faculty of Engineering \\ Universidad Cooperativa de Colombia, Bogotá
}

